Pacific Northwest

National Laboratory

Operated by Battelle for the

U.S. Department of Energy

\title{
Comparison of the 2004 Supplement to the IECC to the Current New York Energy Conservation Code - Residential Buildings
}

R. G. Lucas

September 2004

Prepared for the U.S. Department of Energy under Contract DE-AC06-76RL01830 


\title{
DISCLAIMER
}

This report was prepared as an account of work sponsored by an agency of the United States Government. Neither the United States Government nor any agency thereof, nor Battelle Memorial Institute, nor any of their employees, makes any warranty, express or implied, or assumes any legal liability or responsibility for the accuracy, completeness, or usefulness of any information, apparatus, product, or process disclosed, or represents that its use would not infringe privately owned rights. Reference herein to any specific commercial product, process, or service by trade name, trademark, manufacturer, or otherwise does not necessarily constitute or imply its endorsement, recommendation, or favoring by the United States Government or any agency thereof, or Battelle Memorial Institute. The views and opinions of authors expressed herein do not necessarily state or reflect those of the United States Government or any agency thereof.

\author{
PACIFIC NORTHWEST NATIONAL LABORATORY \\ operated by \\ BATTELLE \\ for the \\ UNITED STATES DEPARTMENT OF ENERGY \\ under Contract DE-AC06-76RL01830
}

Printed in the United States of America

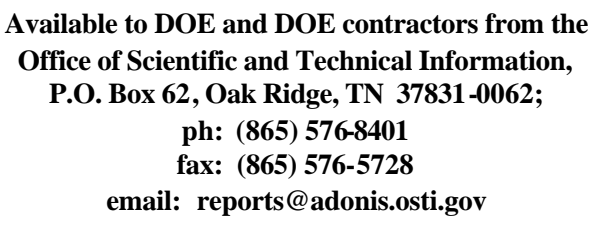

Available to the public from the National Technical Information Service, U.S. Department of Commerce, 5285 Port Royal Rd., Springfield, VA 22161 ph: (800) 553-6847 fax: $(703) 605-6900$

email: orders@ntis.fedworld.gov online ordering: http://www.ntis.gov/ordering.htm (3) This document was printed on recycled paper. 


\title{
Comparison of the 2004 Supplement to the IECC to the Current New York Energy Conservation Code - Residential Buildings
}

\author{
R. G. Lucas
}

September 2004

Prepared for

the U.S. Department of Energy

under Contract DE-AC06-76RL01830

Pacific Northwest National Laboratory

Richland, Washington 99352 


\section{Summary}

The New York State Department of State, Division of Code Enforcement and Administration is in the process of starting the revision cycle for its building codes, including the Energy Conservation Construction Code (International Code Council 2002) and the energy conservation portion of its residential code. As part of this process, New York is considering adopting the International Code Council's (ICC) International Energy Conservation Code (IECC), including the 2004 Supplement. This code incorporates the U.S. Department of Energy code change proposal (EC48-03/04) as approved with modification by the responsible ICC committee.

The New York State Department of State requested the U.S. Department of Energy (DOE) to prepare a report comparing the effects on energy usage as a result of implementation of the 2004 Supplement to the IECC with the current New York code. The report had to determine whether additional costs of compliance with the proposal would be equal to or less than the present value of anticipated energy cost savings over a 10-year period. Under DOE's direction, Pacific Northwest National Laboratory (PNNL) completed the requested assessment of the potential code upgrade.

PNNL determined that 2004 Supplement provides requirements similar in stringency to the current New York code, which is based on the 2001 Supplement to the 2000 IECC. The 2004 Supplement is much easier to use and understand. The impacts of the new requirements in the 2004 Supplement (the prescriptive packages) are relatively modest, in most cases. The net present value of all costs in the first 10 years is positive, except in areas above 7000 heating degree-days, where basement ceiling insulation is used. With the exceptions of Rockland, Orange, Putnam, and, to a lesser extent, Dutchess counties, the first cost increase, when the prescriptive package approach is used, is estimated to be less than $\$ 300$ for a typical house. Impacts will be higher or lower, if the window area of the building is, respectively, below or above $15 \%$ of the wall area. These impacts will only apply if the REScheck software is not used, because REScheck will remain unchanged from the version currently used in New York (at the request of the New York Department of State). 


\section{Table of Contents}

Summary ............................................................................................................................... iii

Introduction ............................................................................................................ 1

Background................................................................................................................................... 3

Summary of the Current New York Code.......................................................... 5

Summary of the 2004 Supplement ........................................................................ 7

Economic Analysis ..................................................................................

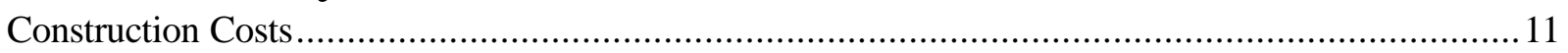

House Prototype and Economic Parameters .......................................................................... 12

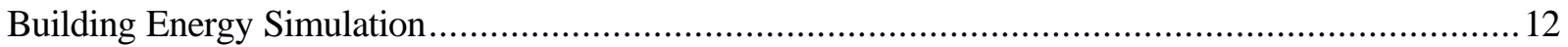

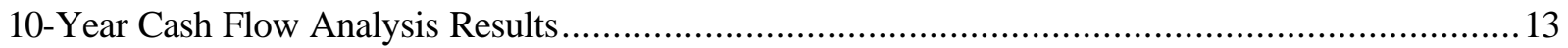

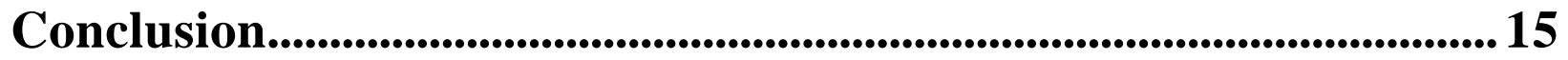

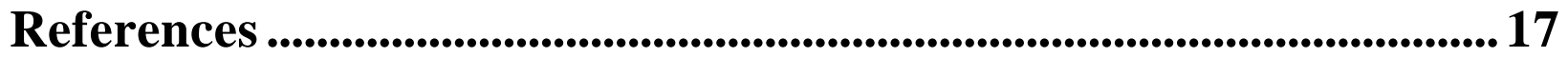




\section{Figures}

Figure 1. Prescriptive Envelope Requirements in the 2004 Supplement ..........................................

\section{Tables}

Table 1. Comparison of the New York Code 15\% Window Area Packages to 2004 IECC Packages...... 10

Table 2. Cost Effectiveness of the 2004 Supplement Envelope Packages......................................... 13 


\section{Introduction}

The New York State Department of State, Division of Code Enforcement and Administration is in the process of starting the revision cycle for its building codes, including the Energy Conservation Construction Code (International Code Council 2002) and the energy conservation portion of its residential code. As part of this process, New York is considering adopting the International Code Council's (ICC) International Energy Conservation Code (IECC), including the 2004 Supplement. This code incorporates the U.S. Department of Energy code change proposal (EC48-03/04) as approved with modification by the responsible ICC committee. The final approval of the 2004 Supplement occurred at the ICC spring hearings in May 2004 ${ }^{\mathrm{a}}$.

The New York State Department of State requested the U.S. Department of Energy (DOE) to prepare a report consisting of two components. The first component is an analysis comparing the effects on energy usage as a result of implementation of the 2004 Supplement to the IECC with the current New York code. The second component is an engineering analysis to determine whether additional costs of compliance with the proposal would be equal to or less than the present value of anticipated energy savings over a 10year period. Under DOE's direction, Pacific Northwest National Laboratory (PNNL) completed the requested assessment of the potential code upgrade.

${ }^{a}$ The 2004 Supplement will not be publis hed until around the end of 2004. 


\section{Background}

This report will assist New York in demonstrating compliance with statutory provisions of New York State Energy Law. Section 11-103(1)(a) of the Energy Law requires that the Energy Code be at least equal to ASHRAE 90-75 and the referenced standards on which it is based. Section 11-103(2) of the Energy Law explicitly provides for compliance with the 10 -year net present value evaluation. The current New York code is based on the 2000 IECC including the 2001 Supplement and a number of revisions specifically for New York. The 10-year present value criterion for revisions to the New York energy efficiency provisions must use the current New York code as the baseline for comparison. 


\section{Summary of the Current New York Code}

The current New York state code is the 2001 Supplement to the 2000 IECC with two notable revisions. Walls of conditioned basements below uninsulated floors must be insulated from the top of the basement wall to a depth of either 24 in. or 48 in. in most of New York. The IECC requires this insulation to extend down to the basement floor. The other revision is increased energy efficiency for envelope measures for homes heated with electricity.

The code contains energy efficiency requirements for space heating, air conditioning, and domestic water heating energy end-uses. The most notable code requirements are ceiling, wall, and foundation insulation; maximum window U-factors; duct insulation; and sealing of ducts and the building envelope in general. A popular method of compliance with the code is the REScheck software developed by DOE. REScheck permits users to take advantage of the flexibility allowed by the code to make trade-offs. For example, wall insulation levels can often be reduced if high efficiency heating equipment is used. 


\section{Summary of the 2004 Supplement}

The 2004 Supplement contains three alternative compliance paths: simplified prescriptive requirements, a total building envelope UA (U-factor multiplied by area) approach, and a simulated performance approach. These approaches also exist in the current New York code. The 2004 Supplement has a simplified prescriptive compliance path that is much simpler to use than those in previous versions of the IECC. The 2004 Supplement has a single table of requirements of insulation R-values and window Ufactors that apply to all low-rise residential buildings. This approach also allows the use of any component with a U-factor equal to or better than the U-factor resulting from the insulation R-value requirement. In contrast, the 2003 IECC contains nine tables of R-value/U-factor requirements, and the user had to calculate the window-to-wall area ratio to determine the appropriate table. The other two compliance paths are the same as previous versions of the IECC, the total UA approach allows any design where the total building thermal envelope UA (sum of U-factor times assembly area) is less than or equal to the total UA, resulting from using the equivalent U-factors of the simplified prescriptive requirements. The simulated performance path compares an annual energy analysis of the proposed design to a standard reference design based on the U-factor criteria in the simplified prescriptive approach. The proposed design must have a calculated annual energy cost equal to or lower than that of the standard reference design.

The 2004 Supplement has a simple and clear map-based format for presenting code requirements that vary by climate, which includes insulation and fenestration requirements. The appropriate climate zone can easily be determined from the U.S. map. The 2004 IECC has eight primary climate zones, from hot locations (i.e., southern Florida) to very cold locations (i.e., northern Alaska). New York falls into three zones (Zones 4, 5, and 6). County borders set climate zone boundaries. To eliminate any doubt about which climate zone a location is placed, a table of climate zones by county is provided in the code. Figure 1 shows the climate zones in New York and the simplified prescriptive envelope requirements for these zones.

As mentioned above, the 2004 Supplement contains a much simpler approach for demonstrating envelope component compliance. Rather than containing a requirement for an average performance for multiple elements within an envelope component, the 2004 IECC establishes individual requirements for each element. As shown in Figure 1, the IECC will require a specific efficiency level for windows, doors, wall insulation, ceiling insulation, etc., for any given climate, regardless of the building design. For example, in all of upstate New York, the proposed rule requires that windows have a U-factor of 0.35 , regardless of the number of windows or the size and shape of the house, apartment building, or condominium. 


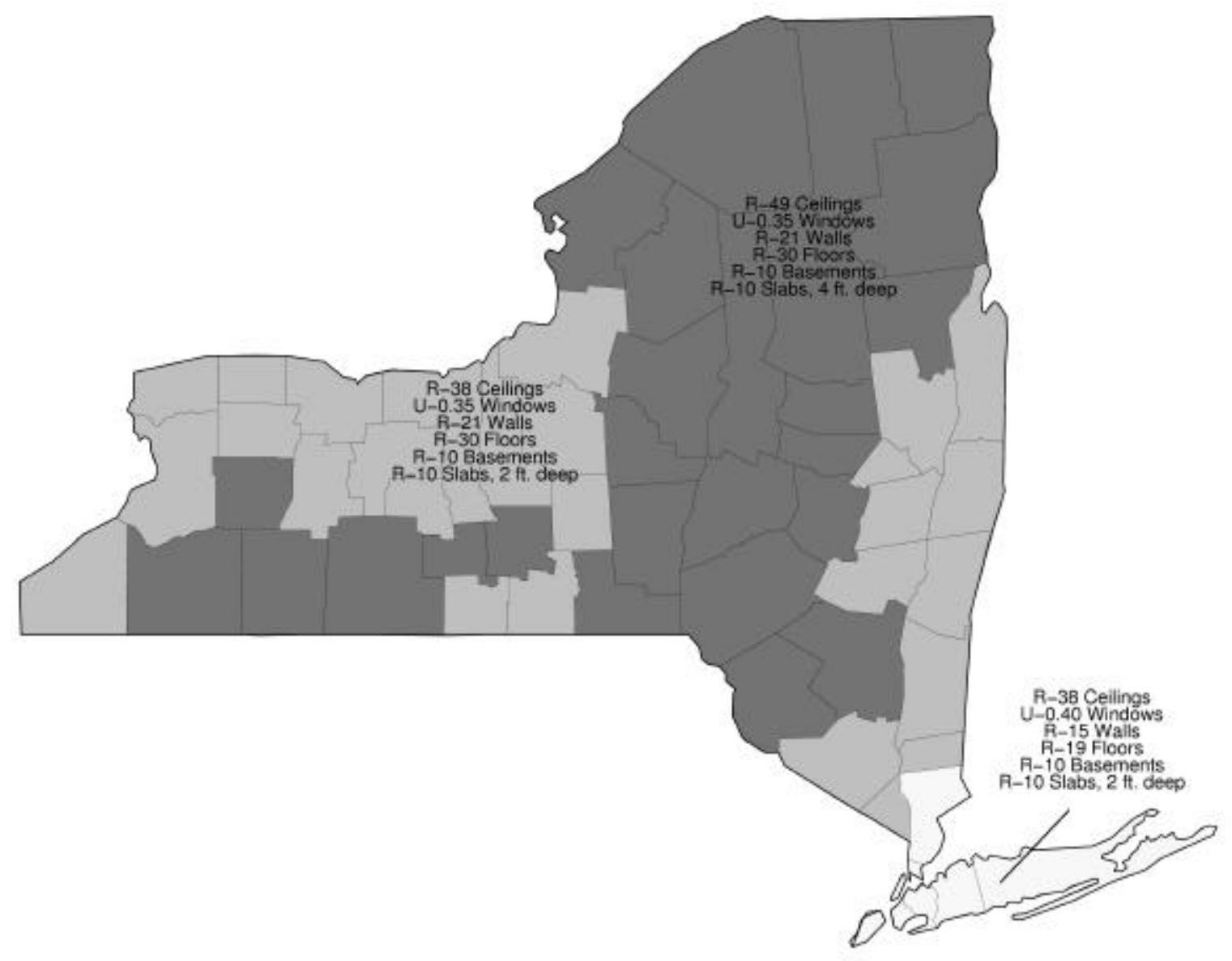

Figure 1. Prescriptive Envelope Requirements in the 2004 Supplement

In contrast, the 2003 IECC and its predecessors (including the current New York code) contain overall envelope component U-factor requirements that include all elements of that component. For example, the IECC has wall U-factor requirements that account for everything within the walls, including windows and doors. Therefore, the IECC requires a window and wall area calculation, which can be complicated and prone to error or misinterpretation. If a house has walls with a high proportion of window and door area, the overall wall thermal requirement is often difficult to meet because windows and doors typically have higher U-factors than insulated walls. This relationship can be seen in the tables in Section 502.2.4 of the 2000 IECC, where the requirements become more stringent as the window area as a percentage of gross exterior wall area increases. Conversely, a house with a low proportion of window and door area might comply with relatively inefficient windows and low insulation R-values. 


\section{Economic Analysis}

The New York State Energy Conservation Construction Code Act states:

The code shall be deemed cost effective if the cost of materials and their installation to meet its standards would be equal to or less than the present value of energy savings that could be expected over a 10-year period in the building in which such materials are installed.

As of the date of this report, the Advisory Committee is planning to update to the IECC, as contained in the 2004 Supplement. But it plans to retain the current REScheck software without any changes as one option for complying with the update to the New York code. As mentioned above, the REScheck software is a popular choice for code compliance because of the flexibility it allows in selecting insulation levels, window U-factors, and heating and cooling equipment efficiency. However, some builders may choose to use the prescriptive requirements provided in the 2004 Supplement, which are similar but not identical to those in the current New York code.

An economic analysis was conducted of the present value of the costs/benefits over the first 10-years for the improvements in the 2004 Supplement compared to prescriptive building envelope criteria in the 2002 Energy Conservation Construction Code of New York State. This comparison is based on the requirements for a house with a $15 \%$ window-to-wall area ratio using the current New York code (Table E602.1(1)). For houses with a lower window-to-wall area percentage, the prescriptive requirements for the current New York code become less stringent, while the New York code becomes more stringent for houses with a higher window percentage. PNNL estimates that the most common window-to-wall area percentages in new houses in New York is about 13\% to 15\%. No data is available for New York, but a recent study of new homes in Massachusetts reported an average window-to-wall area of $14.5 \%$ (Xenergy 2001a). New York Department of State staff have indicated they will modify the 2004 Supplement to retain the basement wall insulation depth requirements that are in the current New York code (2-feet down from top of wall in downstate New York, 4-feet down in most of upstate New York).

Table 1 compares the main envelope components requirements by county. The 2004 IECC has at least one component more stringent in all counties. The New York code has some components in some locations that are more stringent than the 2004 Supplement; this cost decrease is not accounted for here, because it is irrelevant in the cost effectiveness test in the New York legislation. Other requirements in the 2004 Supplement are consistent with those in current New York code (R-8 duct insulation, seal sources of leakage in the building envelope and ducts, etc.). 
Table 1. Comparison of the New York Code 15\% Window Area Packages to 2004 IECC Packages

\begin{tabular}{|c|c|c|c|c|c|c|c|c|c|c|}
\hline \multirow[b]{2}{*}{ County } & \multirow{2}{*}{\multicolumn{2}{|c|}{$\begin{array}{c}\text { Ceiling R- } \\
\text { Value } \\
\text { NY }\end{array}$}} & \multicolumn{2}{|c|}{ Wall R-Value } & \multirow{2}{*}{\multicolumn{2}{|c|}{$\begin{array}{c}\text { Window U- } \\
\text { Factor } \\
\text { NY }\end{array}$}} & \multirow{2}{*}{\multicolumn{2}{|c|}{$\begin{array}{r}\text { Floor R-Value } \\
\text { NY }\end{array}$}} & \multirow{2}{*}{\multicolumn{2}{|c|}{$\begin{array}{r}\text { Basement } \\
\text { Wall R-Value } \\
\text { NY }\end{array}$}} \\
\hline & & & 2004 & $\begin{array}{l}\text { NY } \\
\text { Code }\end{array}$ & & & & & & \\
\hline Albany & 38 & 49 & 21 & 21 & 0.35 & 0.35 & 30 & 21 & 13 & 11 \\
\hline Allegany & 49 & 49 & 21 & 21 & 0.35 & 0.35 & 30 & 21 & 13 & 11 \\
\hline Bronx & 38 & 38 & 15 & 18 & 0.4 & 0.45 & 19 & 19 & 13 & 9 \\
\hline Broome & 49 & 49 & 21 & 21 & 0.35 & 0.35 & 30 & 21 & 13 & 11 \\
\hline Cattaraugus & 49 & 49 & 21 & 21 & 0.35 & 0.35 & 30 & 21 & 13 & 11 \\
\hline Cayuga & 38 & 49 & 21 & 21 & 0.35 & 0.35 & 30 & 21 & 13 & 11 \\
\hline Chautauqua & 38 & 49 & 21 & 21 & 0.35 & 0.35 & 30 & 21 & 13 & 11 \\
\hline Chemung & 38 & 49 & 21 & 21 & 0.35 & 0.35 & 30 & 21 & 13 & 11 \\
\hline Chenango & 49 & 49 & 21 & 21 & 0.35 & 0.35 & 30 & 21 & 13 & 11 \\
\hline Clinton & 49 & 49 & 21 & 21 & 0.35 & 0.35 & 30 & 21 & 13 & 11 \\
\hline Columbia & 38 & 49 & 21 & 21 & 0.35 & 0.35 & 30 & 21 & 13 & 11 \\
\hline Cortland & 38 & 49 & 21 & 21 & 0.35 & 0.35 & 30 & 21 & 13 & 11 \\
\hline Delaware & 49 & 49 & 21 & 21 & 0.35 & 0.35 & 30 & 21 & 13 & 11 \\
\hline Dutchess & 38 & 38 & 21 & 18 & 0.35 & 0.35 & 30 & 21 & 13 & 10 \\
\hline Erie & 38 & 49 & 21 & 21 & 0.35 & 0.35 & 30 & 21 & 13 & 11 \\
\hline Essex & 49 & 49 & 21 & 21 & 0.35 & 0.35 & 30 & 21 & 13 & 18 \\
\hline Franklin & 49 & 49 & 21 & 21 & 0.35 & 0.35 & 30 & 21 & 13 & 18 \\
\hline Fulton & 49 & 49 & 21 & 21 & 0.35 & 0.35 & 30 & 21 & 13 & 11 \\
\hline Genesee & 38 & 49 & 21 & 21 & 0.35 & 0.35 & 30 & 21 & 13 & 11 \\
\hline Greene & 38 & 49 & 21 & 21 & 0.35 & 0.35 & 30 & 21 & 13 & 11 \\
\hline Hamilton & 49 & 49 & 21 & 21 & 0.35 & 0.35 & 30 & 21 & 13 & 18 \\
\hline Herkimer & 49 & 49 & 21 & 21 & 0.35 & 0.35 & 30 & 21 & 13 & 11 \\
\hline Jefferson & 49 & 49 & 21 & 21 & 0.35 & 0.35 & 30 & 21 & 13 & 11 \\
\hline Kings & 38 & 38 & 15 & 16 & 0.4 & 0.45 & 19 & 19 & 13 & 9 \\
\hline Lewis & 49 & 49 & 21 & 21 & 0.35 & 0.35 & 30 & 21 & 13 & 11 \\
\hline Livingston & 38 & 49 & 21 & 21 & 0.35 & 0.35 & 30 & 21 & 13 & 11 \\
\hline Madison & 49 & 49 & 21 & 21 & 0.35 & 0.35 & 30 & 21 & 13 & 11 \\
\hline Monroe & 38 & 49 & 21 & 21 & 0.35 & 0.35 & 30 & 21 & 13 & 11 \\
\hline Montgomery & 49 & 49 & 21 & 21 & 0.35 & 0.35 & 30 & 21 & 13 & 11 \\
\hline Nassau & 38 & 38 & 15 & 18 & 0.4 & 0.45 & 19 & 19 & 13 & 9 \\
\hline New York & 38 & 38 & 15 & 16 & 0.4 & 0.45 & 19 & 19 & 13 & 9 \\
\hline Niagara & 38 & 49 & 21 & 21 & 0.35 & 0.35 & 30 & 21 & 13 & 11 \\
\hline Oneida & 49 & 49 & 21 & 21 & 0.35 & 0.35 & 30 & 21 & 13 & 11 \\
\hline Onondaga & 38 & 49 & 21 & 21 & 0.35 & 0.35 & 30 & 21 & 13 & 11 \\
\hline Ontario & 38 & 49 & 21 & 21 & 0.35 & 0.35 & 30 & 21 & 13 & 11 \\
\hline Orange & 38 & 38 & 21 & 18 & 0.35 & 0.4 & 30 & 21 & 13 & 10 \\
\hline Orleans & 38 & 49 & 21 & 21 & 0.35 & 0.35 & 30 & 21 & 13 & 11 \\
\hline Oswego & 38 & 49 & 21 & 21 & 0.35 & 0.35 & 30 & 21 & 13 & 11 \\
\hline Otsego & 49 & 49 & 21 & 21 & 0.35 & 0.35 & 30 & 21 & 13 & 11 \\
\hline Putnam & 38 & 38 & 21 & 18 & 0.35 & 0.4 & 30 & 21 & 13 & 10 \\
\hline Queens & 38 & 38 & 15 & 16 & 0.4 & 0.45 & 19 & 19 & 13 & 9 \\
\hline Rensselaer & 38 & 49 & 21 & 21 & 0.35 & 0.35 & 30 & 21 & 13 & 11 \\
\hline Richmond & 38 & 38 & 15 & 18 & 0.4 & 0.45 & 19 & 19 & 13 & 9 \\
\hline Rockland & 38 & 38 & 21 & 18 & 0.35 & 0.4 & 30 & 21 & 13 & 10 \\
\hline Saratoga & 38 & 49 & 21 & 21 & 0.35 & 0.35 & 30 & 21 & 13 & 11 \\
\hline
\end{tabular}


Table 1. Continued

\begin{tabular}{|c|c|c|c|c|c|c|c|c|c|c|}
\hline \multirow[b]{2}{*}{ County } & \multicolumn{2}{|c|}{$\begin{array}{c}\text { Ceiling R-Value } \\
\text { NY }\end{array}$} & \multicolumn{2}{|c|}{$\begin{array}{c}\text { Wall R-Value } \\
\text { NY }\end{array}$} & \multicolumn{2}{|c|}{$\begin{array}{c}\text { Window U-Factor } \\
\text { NY }\end{array}$} & \multicolumn{2}{|c|}{ Floor R-Value } & \multicolumn{2}{|c|}{$\begin{array}{c}\text { Basement } \\
\text { Wall R-Value }\end{array}$} \\
\hline & 2004 & Code & 2004 & Code & 2004 & & 2004 & & 2004 & Code \\
\hline Schenectady & 38 & $\overline{499}$ & 21 & 21 & 0.35 & 0.35 & 25 & 21 & 13 & 11 \\
\hline Schoharie & 49 & 49 & 21 & 21 & 0.35 & 0.35 & 30 & 21 & 13 & 11 \\
\hline Schuyler & 49 & 49 & 21 & 21 & 0.35 & 0.35 & 30 & 21 & 13 & 11 \\
\hline Seneca & 38 & 49 & 21 & 21 & 0.35 & 0.35 & 25 & 21 & 13 & 11 \\
\hline St Lawrence & 49 & 49 & 21 & 21 & 0.35 & 0.35 & 30 & 21 & 13 & 11 \\
\hline Steuben & 49 & 49 & 21 & 21 & 0.35 & 0.35 & 30 & 21 & 13 & 11 \\
\hline Suffolk & 38 & 38 & 15 & 18 & 0.4 & 0.45 & 19 & 19 & 13 & 9 \\
\hline Sullivan & 49 & 49 & 21 & 21 & 0.35 & 0.35 & 30 & 21 & 13 & 11 \\
\hline Tioga & 38 & 49 & 21 & 21 & 0.35 & 0.35 & 25 & 21 & 13 & 11 \\
\hline Tompkins & 49 & 49 & 21 & 21 & 0.35 & 0.35 & 30 & 21 & 13 & 11 \\
\hline Ulster & 49 & 49 & 21 & 21 & 0.35 & 0.35 & 30 & 21 & 13 & 11 \\
\hline Warren & 49 & 49 & 21 & 21 & 0.35 & 0.35 & 30 & 21 & 13 & 11 \\
\hline Washington & 38 & 49 & 21 & 21 & 0.35 & 0.35 & 25 & 21 & 13 & 11 \\
\hline Wayne & 38 & 49 & 21 & 21 & 0.35 & 0.35 & 25 & 21 & 13 & 11 \\
\hline Westchester & 38 & 38 & 15 & 18 & 0.4 & 0.4 & 19 & 21 & 13 & 10 \\
\hline Wyoming & 49 & 49 & 21 & 21 & 0.35 & 0.35 & 30 & 21 & 13 & 11 \\
\hline Yates & 38 & 49 & 21 & 21 & 0.35 & 0.35 & 25 & 21 & 13 & 11 \\
\hline
\end{tabular}

The increases in stringency in the 2004 Supplement can be summarized as follows:

1) Floor insulation increases from R-21 to R-30 in most counties

2) Basement wall insulation increases from R-9, R-10, or R-11 to R-13 in most counties

3) Window U-factors decrease from U-0.45 to U-0.40 or from U-0.40 to U-0.35, for some downstate counties

4) Above-grade wall insulation increases from R-18 to R-21 in some counties.

\section{Construction Costs}

Construction cost increases have been estimated for these improvements. For the increase in wall insulation from R-19 ${ }^{\mathrm{b}}$ to R-21, California Database for Energy Efficient Resources (DEER) (Xenergy, Inc. 2001b) reports an installed cost of $\$ 0.44 / \mathrm{ft}^{2}$. However, an Oregon study estimates the cost for the R19 to R-21 increment at only $\$ 0.10 / \mathrm{ft}^{2}$ (Oikos 1994). The Oregon source is older, but insulation costs have not changed greatly in the last decade and the R-21 insulation was (and is) common (a code requirement) in Oregon but is uncommon in California. R-21 insulation will be common in New York with the new code requirement and therefore, the Oregon incremental cost was used here in the cost effectiveness analysis.

${ }^{\mathrm{b}}$ The prescriptive requirement in the current New York code is actually R-18 in the relevant counties, but this will typically be met with R-19 batt insulation as there is no R-18 fiberglass batt product available. An R-13 batt plus R-5 sheathing is an acceptable option but builders more often use R-19 batts. 
The 2004 Supplement requires interior basement wall insulation of R-13 compared to R-11 in the current New York code ${ }^{\mathrm{c}}$. The DEER survey provides an incremental material cost of $\$ 0.05 / \mathrm{ft}^{2}$ for R-13 wall insulation compared to R-11. Assuming a $40 \%$ overhead and profit markup, this is a cost of $\$ 0.07 / \mathrm{ft}^{2}$.

The 2004 IECC requires R-30 floor insulation in most of New York, whereas the current code requires R21 , in these locations. R.S. Means (2003) reports an incremental installed cost of $\$ 0.37 / \mathrm{ft}^{2}$ (include overhead and profit) for R-30 floor insulation, compared to R-19. The DEER database reports $\$ 0.34 / \mathrm{ft}^{2}$ for the same improvement. Assuming a $\$ 0.37 / \mathrm{ft}^{2}$ cost increment compared to R-19, less the $\$ 0.10 / \mathrm{ft}^{2}$ cost increment for from R-19 to R-21, the net cost increment is $\$ 0.27 / \mathrm{ft}^{2}$, for from R-21 to R-30 floor insulation.

There are many counties in upstate New York (Albany, Onondaga, Erie, etc.) where the floor and basement wall insulation requirements increase in the 2004 Supplement, but the ceiling insulation level decreases from R-49 to R-38. The cost decrease from the reduced ceiling insulation should approximately offset the cost increase of the floor or basement wall insulation. For example, an extrapolation of R.S. Means ceiling insulation costs for R-38 yields an estimated incremental cost of $\$ 0.25 / \mathrm{ft}^{2}$ for $\mathrm{R}-49$. This is only $\$ 0.02 / \mathrm{ft}^{2}$ more than the incremental cost of $\mathrm{R}-30$ floor insulation.

In downstate New York, the 2004 Supplement requires fenestration to have a U-factor that is 0.05 better than the current New York code (either from 0.45 to 0.40 or from 0.40 to 0.35 , depending on the county). It is difficult to quantify the cost for this, because this improvement does not correspond to a specific change in window types, materials, or technologies. Even the least stringent New York code requirement of U-0.45 will normally necessitate low-emissivity glass. The improvements to U-0.40 or U-0.35 may come from improved frame construction or design, improved spacers, improved air space thickness between the panes of glass, or lower emissivity coatings. A study from the Pacific Northwest estimated a cost of $\$ 0.08 / \mathrm{ft}^{2}$ per 0.01 improvement in window U-factor over this range of U-factors (Quantec 2002). This cost was used here.

\section{House Prototype and Economic Parameters}

A natural gas furnace, central air conditioning, and a $2000 \mathrm{ft}^{2}$, two-story house were assumed in all locations. Air ducts were assumed to be $75 \%$ efficient in delivering conditioned air. Natural gas prices were assumed to be $\$ 1.09 /$ therm, and electricity was assumed to be 15 cents/kWh (summer) (EIA 2004). The mortgage parameters were set to a 30 -year mortgage with a $7 \%$ interest rate, $1.6 \%$ points and fees, and a $10 \%$ down payment. A property tax rate of $2 \%$ was assumed, and the income tax rate was $25 \%$ for federal and $7 \%$ for state taxes (for mortgage interest deductions). The inflation rate was set to 3\%.

\section{Building Energy Simulation}

The DOE 2.1E energy simulation software was used. Input parameters are consistent with those specified in the Chapter 4 "Systems Analysis" compliance approach in the 2000 IECC.

\footnotetext{
${ }^{\mathrm{c}}$ It is assumed here that the basement wall insulation depth requirements in the current New York State will remain unchanged at $2 \mathrm{ft}$. downstate, $4 \mathrm{ft}$. upstate. Additionally, R-11 batt insulation is assumed to be used to comply with the R-9 and R-10 requirement as there is no fiberglass batt products available with a R-9 or R-10 R-value.
} 


\section{0-Year Cash Flow Analysis Results}

Table 2 shows the first cost increase, the annual energy savings, and the net present value of the first 10 years of costs and benefits, from the improved energy efficiency of the 2004 Supplement envelope packages. The "heated basement" columns are for a house with a heated basement and basement wall insulation; the "unheated basement" columns are for a house with an unheated basement and insulation in the floor above the basement. The first cost is simply the incremental construction cost impacts- this does not account for the impacts of a mortgage. The present value includes energy costs, all mortgage costs (including tax deductions), and property tax. Positive net present values in Table 2 indicate the 2004 Supplement saves money for the homeowner; negative net present vales represent increases costs to the homeowner. The 2004 Supplement will save money, in all cases except where the floor insulation is increased to R-30, in counties over 7000 heating degree-days.

Table 2. Cost Effectiveness of the 2004 Supplement Envelope Packages

\begin{tabular}{|c|c|c|c|c|c|c|c|}
\hline \multirow[b]{2}{*}{ Location } & \multirow{2}{*}{$\begin{array}{l}\text { Energy } \\
\text { Efficiency } \\
\text { Improvement }\end{array}$} & \multicolumn{2}{|c|}{$\begin{array}{l}\text { First Cost } \\
\text { Increase }(\$)\end{array}$} & \multicolumn{2}{|c|}{$\begin{array}{l}\text { Annual Energy Cost } \\
\text { Savings (\$) }\end{array}$} & \multicolumn{2}{|c|}{$\begin{array}{l}\text { Net Present Value } \\
\text { Savings for first } 10 \\
\text { years }(\$)\end{array}$} \\
\hline & & $\begin{array}{l}\text { Heated } \\
\text { Basement }\end{array}$ & $\begin{array}{l}\text { Unheated } \\
\text { Basement }\end{array}$ & $\begin{array}{l}\text { Heated } \\
\text { Basement }\end{array}$ & $\begin{array}{l}\text { Unheated } \\
\text { Basement }\end{array}$ & $\begin{array}{l}\text { Heated } \\
\text { Basement }\end{array}$ & $\begin{array}{l}\text { Unheated } \\
\text { Basement }\end{array}$ \\
\hline $\begin{array}{l}\text { New York } \\
\text { City and } \\
\text { Long Island }\end{array}$ & $\begin{array}{l}\text { U-0.40 } \\
\text { windows, } \\
\text { R-13 } \\
\text { basement } \\
\text { walls }\end{array}$ & 151 & 133 & 34 & 28 & 141 & 104 \\
\hline $\begin{array}{l}\text { Rockwell, } \\
\text { Orange, and } \\
\text { Putnam } \\
\text { Counties }\end{array}$ & $\begin{array}{l}\text { U-0.35 } \\
\text { windows, R- } \\
21 \text { walls, R- } \\
13 \text { basement } \\
\text { walls, R-30 } \\
\text { floors }\end{array}$ & 333 & 585 & 62 & 66 & 203 & 6 \\
\hline $\begin{array}{l}7000 \\
\text { Heating } \\
\text { Degree Days } \\
\text { - Elmira, } \\
\text { Binghamton, } \\
\text { Utica, } \\
\text { Waterton, } \\
\text { etc. }\end{array}$ & $\begin{array}{l}\text { R-13 } \\
\text { basement } \\
\text { walls, R-30 } \\
\text { floors }\end{array}$ & 36 & 270 & 9 & 15 & 43 & -127 \\
\hline $\begin{array}{l}\text { State } \\
\text { Average }^{1}\end{array}$ & & 150 & 217 & 32 & 30 & 129 & 44 \\
\hline
\end{tabular}




\section{Conclusion}

The 2004 Supplement provides requirements similar in stringency to the 2000 and 2003 IECC. The 2004 Supplement is much easier to use and understand. The impacts of the new requirements in the 2004 Supplement (the prescriptive packages) are relatively modest, in most cases. The net present value of all costs in the first 10 years is positive, except in areas above 7000 heating degree-days, where basement ceiling insulation is used. With the exceptions of Rockland, Orange, Putnam, and, to a lesser extent, Dutchess counties, the first cost increase, when the prescriptive package approach is used, is estimated to be less than $\$ 300$ for a typical house. Impacts will be higher or lower, if the window area of the building is, respectively, below or above $15 \%$ of the wall area. These impacts will only apply if the REScheck software is not used, because REScheck will remain unchanged from the version currently used in New York (at the request of the New York Department of State). 


\section{References}

Energy Information Administration (EIA). 2003. "Electric Power Monthly." DOE/EIA-0226.

U.S. Department of Energy, Washington, D.C.

Energy Information Administration (EIA). 2004. "Natural Gas Monthly.” DOE/EIA-0130. U.S.

Department of Energy, Washington, D.C.

International Code Council. 2000. "International Energy Conservation Code.” Country Club Hills, Illinois.

International Code Council. 2002. "Energy Conservation Construction Code of New York State." Country Club Hills, Illinois.

R.S. Means Company. 2003. Residential Cost Data 23rd Edition. Kingston, Massachusetts.

Oikos. 1994. Energy Source Builder. Iris Communications, Inc. Lorane, Oregon.

Quantec. 2002. Market Progress Evaluation Report for the Energy Star Windows Project. Northwest Energy Efficiency Alliance, Portland, Oregon.

Xenergy. 2001a. "Impact Analysis of the Massachusetts 1998 Energy Code Revisions." Oakland, California.

http://www.mass.gov/bbrs/Mass_Code_Evaluation_Final_Report.pdf

Xenergy. 2001b. Database for Energy Efficient Resources Update Study: Final Report. Oakland, California. http://www.energy.ca.gov/deer/2001_DEER_Update_Study.PDF 